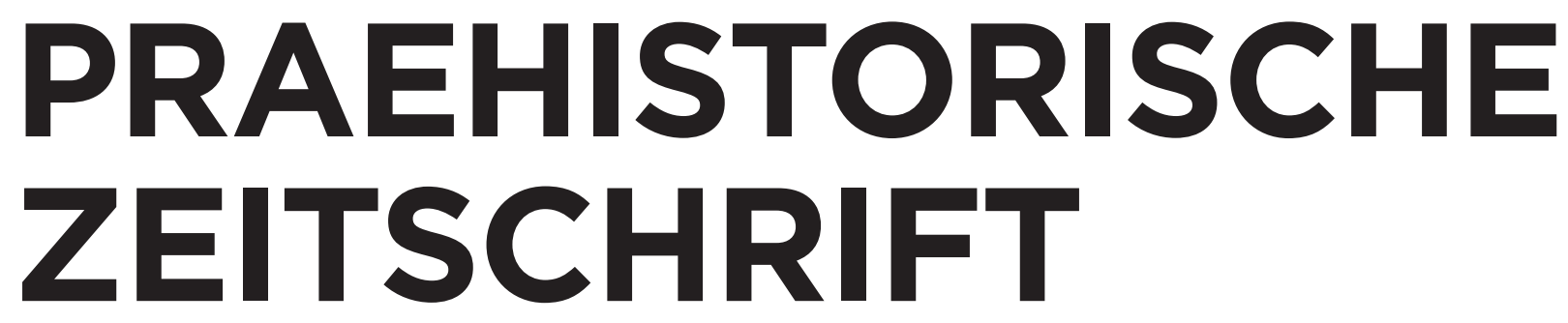

BEGRÜNDET VON

Carl Schuchhardt

Karl Schumacher

Hans Seger

FORTGEFÜHRT VON

Wilhelm Unverzagt

Herbert Jankuhn

Vladimir Milojčić

Rafael von Uslar

Niels Bantelmann

Michael Müller-Wille

Karl Peschel

Bernhard Hänsel

Karl-Heinz Willroth

HERAUSGEGEBEN VON

François Bertemes, Halle/Wittenberg

Philippe Della Casa, Zürich

Wolfram Schier, Berlin

Matthias Wemhoff, Berlin

DE GRUYTER 


\section{ANSCHRIFTEN DER BEITRÄGER UND BEITRÄGERINNEN DIESES HEFTES}

Małgorzata Daszkiewicz: Freie Universität Berlin, Institut für Prähistorische Archäologie, Fabeckstraße 23-25, 14195 Berlin; ARCHEA, Warszawa. E-Mail: m.dasz@wp.pl

Stefan Dreibrodt: Kiel University, Institute for Ecosystem Research; CRC 1266 „Scales of Transformation - HumanEnvironmental Interaction in Prehistoric and Archaic Societies". E-Mail: sdreibrodt@ecology.uni-kiel.de

Martin Furholt: University of Oslo, Department of Archaeology, Conservation and History.

E-Mail: martin.furholt@iakh.uio.no

Antonia Hofmann: University of Applied Science Berlin, School of Design and Culture.

E-Mail: Antonia.Hofmann@HTW-Berlin.de

Robert Hofmann: Kiel University, Institute for Prehistoric and Protohistoric Archaeology; CRC 1266 "Scales of Transformation - Human-Environmental Interaction in Prehistoric and Archaic Societies".

E-Mail: robert.hofmann@ufg.uni-kiel.de

Maciej Kaczmarek: Adam Mickiewicz University, Faculty of Archaeology, Uniwersytetu Poznańskiego 7, 61-614 Poznań. E-Mail: maciej.kaczmarek@amu.edu.pl

Jörg Kleemann: Uniwersytet Szczeciński, Instytut Historii i Stosunków Międzynarodowych, ul. Krakowska 71-79, 71-017 Szczecin. E-Mail: jkarchus@aol.com

Aneta Kuzioła: ul. Armii Krajowej 19/9, PL-21-040 Świdnik. E-Mail: anne.raven86@gmail.com

Piotr Luczkiewicz: Uniwersytet Marii Curie-Skłodowskiej, Instytut Archeologii, Plac M. Curie-Skłodowskiej 4, PL-20-031 Lublin; Freie Universität Berlin, Institut für Prähistorische Archäologie, Fabeckstraße 23-25, 14195 Berlin. E-Mail: piotr_luczkiewicz@hotmail.com

Sarah Martini: Yale University, Department of Anthropology, New Haven, USA. E-Mail: sjmartini16@gmail.com Aleksandar Medović: Department of Archaeology, Novi Sad. E-Mail: aleksandar.medovic@muzejvojvodine.org.rs Ildiko Medović: Museum of Vojvodina, Novi Sad. E-Mail: ildicom2@gmail.com

Ewelina Miśta-Jakubowska: National Centre for Nuclear Research, Andrzeja Soltana 2, 05-400 Otwock. E-Mail: Ewelina.Mista@ncbj.gov.pl

Constantin Rauer: Gleditschstraße 80, 10823 Berlin. E-Mail: constantin.rauer@gmx.de

Sophie C. Schmidt: Archäoinformatik, Archäologisches Institut der Universität zu Köln, Albertus-Magnus-Platz, 50923 Köln. OrcID: 0000-0003-4696-2101. E-mail: s.c.schmidt@uni-koeln.de

Kalina Skóra: Institute of Archaeology and Ethnology, Polish Academy of Sciences, Tylna 1, 90-364 Lódź. E-Mail: kalina.skora@tlen.pl

Tijana Stanković-Pešterac: Museum of Vojvodina, Novi Sad. E-Mail: tijana.pesterac@muzejvojvodine.org.rs

Grzegorz Żabiński: Institute of History, Jan Długosz University in Częstochowa, al. Armii Krajowej 36a, 42-200 Częstochowa. E-Mail: g.zabinski@gmail.com 


\section{Inhalt}

\section{Abhandlungen}

Constantin Rauer

Die Höhle Cougnac.

Gewalt und Religion

in der Höhlenmalerei -307

Robert Hofmann, Aleksandar Medović, Martin Furholt, Ildiko Medović, Tijana Stanković Pešterac,

Stefan Dreibrodt, Sarah Martini, Antonia Hofmann

Late Neolithic multicomponent sites of the Tisza

region and the emergence of centripetal settlement

layouts -351

Maciej Kaczmarek

Urnfields in the middle Oder basin - a perspective of a Lubusz-Greater Polish territorial community — 379
Małgorzata Daszkiewicz, Piotr Łuczkiewicz, Jörg Kleemann, Aneta Kuzioła

What shall we put in the grave? Archaeometric analyses of ceramics from a late Pre-Roman, Roman and Migration period cemetery in Malbork-Wielbark, northern Poland -414

Kalina Skóra, Grzegorz Żabiński, Ewelina Miśta-Jakubowska

Weaponry of the Przeworsk Culture in the light of metallographic examinations. The case of the cemetery in Raczkowice - 454

Sophie C. Schmidt

Siedlungsgrößen und Abstände zwischen Siedlungsstandorten - eine geostatistische Analyse von Transektdaten — 499 